\title{
In vitro effect of leptin on anterior pituitary cells LH secretory activity during early pregnancy in pig
}

\author{
G. Siawrys' ${ }^{1}$ A. Gajewska² \\ ${ }^{1}$ Department of Animal Physiology, Faculty of Biology and Biotechnology, \\ University of Warmia and Mazury in Olsztyn, Oczapowskiego 1A, 10-719 Olsztyn-Kortowo, Poland \\ ${ }^{2}$ Department of Neuroendocrinology, The Kielanowski Institute of Animal Physiology and Nutrition, \\ Polish Academy of Science, 05-110 Jabłonna n. Warsaw, Poland
}

\begin{abstract}
Leptin modulates reproductive activity but its potential influence on LH secretion from anterior pituitary (AP) cells during implantation period in pigs (days 14-16 of pregnancy) remained unexplored. This study focused on determination whether leptin affects basal and GnRH-induced LH secretion and intracellular accumulation and whether leptin receptor (OB-Rb) mRNA is expressed in the AP gland during implantation in pigs. Four individual AP glands were developed into separate primary cultures. $2 \times 10^{5}$ cells $/ \mathrm{ml}$ were preincubated $(72 \mathrm{~h})$ and next, for $3.5 \mathrm{~h}$, experimentally treated with GnRH $(100 \mathrm{ng} / \mathrm{ml})$, leptin $\left(10^{-11}, 10^{-9}, 10^{-7}, 10^{-6} \mathrm{M}\right)$ alone, or given in respective combinations with GnRH. In the AP gland, OB-Rb mRNA expression was determined by real-time PCR method. Leptin activated LH secretion and its concentration-dependent effect was observed as stimulation shown in a full range tested (culture 1) and exhibited only at $10^{-6} \mathrm{M}$ (culture 2). A pooled data analysis revealed that basal LH secretion increased at $10^{-9}, 10^{-7}$ and $10^{-6} \mathrm{M}$, but GnRH-induced LH release decreased at $10^{-6} \mathrm{M}$. Leptin down-regulated GnRH-induced LH secretion in all cultures, but only culture 3 exhibited sensitivity for all concentrations tested. Basal LH accumulation was activated in culture $1\left(\right.$ at $\left.10^{-11} \mathrm{M}\right)$ and inhibited in culture $4\left(\right.$ at $\left.10^{-9} \mathrm{M}\right)$. In the presence of GnRH leptin up-regulated LH accumulation with individual culture leptin-sensitivity (culture 1-3), while down-regulated LH accumulation in culture 4. Obtained data indicate that OB-Rb mRNA is expressed in the AP gland and leptin alone and in combination with GnRH specifically modulates LH activity during early pregnancy in pigs.
\end{abstract}

Key words: leptin, OB-Rb, GnRH, LH secretion/accumulation, pituitary, pig 


\section{Introduction}

Reproduction success depends on the coordinated action of the hypothalamus, pituitary and gonads with an array of central and peripheral signals interplay to modulate synthesis and release of several hormones of the reproductive axis. The secretory action of pituitary gonadotropes, which synthesize and release luteinizing hormone (LH) and follicle-stimulating hormone (FSH), results from a complex neuroendocrine control network in which hypothalamic gonadoliberin $(\mathrm{GnRH})$ plays a central role. This decapeptide conveys these regulatory signals down to the pituitary level to dictate the specific pattern of gonadotropin release. GnRH displays a bimodal pattern of release, episodic versus-surge-like where gonadal steroids play a crucial role. In both sexes the tonic mode of GnRH secretion is regulated by gonadal steroids negative feedback mechanism exerted both at the hypothalamic and pituitary level. In addition, adult females also exhibit a positive, estradiol-dependent feedback of GnRH release as a unique surge-like peak that evokes ovulation by means of the consequent surge of luteinizing hormone release (Counis et al. 2009, Naor and Huhtaniemi 2013). Besides GnRH and gonadal steroids, LH synthesis and release is also controlled by stimulatory and inhibitory influences of other hypothalamic-derived hormones such as: vasopressin, oxytocin (Bogacka et al. 2002), galanin, substance $\mathrm{P}$, opioids (Estienne and Barb 2005), ghrelin, orexin (Kirsz et al. 2014) and recently discovered kisspeptin (Ezzat et al. 2010) also controls LH release. Extensive studies, primarily on ruminants and laboratory rodents, have established that leptin might be also directly or indirectly involved in the regulation of $\mathrm{LH}$ secretion acting at both the hypothalamic and anterior pituitary levels (Barb et al. 2004). Leptin, a 16-kDa protein named $\mathrm{OB}$, encoded by the obese $(o b)$ gene, is secreted mainly by adipocytes. Although initially leptin was recognized as a crucial regulator of food intake, body fat mass and energy expenditure (Pelleymounter et al. 1995) further studies revealed that this hormone is also implicated in the hypothalamic-pituitary regulation of the gonadotropin-gonadal axis, therefore it affects the reproductive processes (Chebab 2014, Perez-Perez et al. 2015). The effect of leptin is mainly mediated via its functional receptor - the long isoform (OB-Rb). It is capable of full signal transduction, acting mainly through JAK-STAT and MAPK (Fruhbeck 2006) pathways activation. Expression of $\mathrm{OB}-\mathrm{Rb}$ has been detected in the hypothalamus and pituitary in the prepuberal gilts and mature pig
(Lin et al. 2000, Siawrys et al. 2007, 2009). So far few studies focused on leptin effects on LH release from pig pituitary cells in pig (Barb et al. 2004, Nonaka et al. 2006, Kosior-Korzecka and Bobowiec 2007) but data concerning this aspect of leptin activity in pregnant pigs is still missing. Therefore, the current studies were designed to (1) examine the direct effect of leptin on basal and GnRH-induced LH secretion and accumulation in porcine AP cells on days 14-16 of pregnancy and (2) to determine whether AP cells express OB-Rb mRNA in this period of pregnancy.

\section{Materials and Methods}

\section{Experimental animals and tissue collection}

The studies were carried out in accordance with the principles and procedures of the Animal Ethics Committee at the University of Warmia and Mazury in Olsztyn, Poland. The experimental animals were post-pubertal 5 crossbred pigs (Polish Landrace $x$ Pietrain), aged 9-10 months, with body weight of $110-130 \mathrm{~kg}$. Females were naturally bred on the second day of oestrus. Stage of pregnancy was detected by ultrasound scanning performed before slaughtering. Additionally, pregnancy status was confirmed by the presence of embryos obtained after flushing of uterine horns with $20 \mathrm{ml}$ of sterile physiological saline.

The choice of 14-16 days of pig pregnancy resulted from crucial role of implantation process exerted in pregnancy maintenance. All tissues: pituitary and medial basal hypothalamus (MBH) were individually collected no later than 10 minutes after slaughter. The pituitary gland was dissected out from sella turcica located in the hollow of the sphenoid bone and AP lobe was separated from posterior neural lobe. MBH was defined as a block of tissue bordered rostrally by the optic chiasma, caudally by the mammillary body, laterally by the hypothalamic sulci and dorsally by $5 \mathrm{~mm}$ in-depth cut. Four isolated AP glands were individually placed in sterile Eagle's Medium (Biomed, Poland) containing antibiotics (penicillin and streptomycin; Polfa, Poland) and nystatin (Sigma-Aldrich, USA) and after enzymatic dispersion used for culture. For real-time PCR (qRT-PCR) analysis AP as well as $\mathrm{MBH}$ (as positive controls) excised from one pig were rapidly frozen in liquid nitrogen and stored at $-80^{\circ} \mathrm{C}$ until extraction of total RNA (Sigma-Aldrich, USA). Blood samples collected from all pigs were centrifuged and stored at $-20^{\circ} \mathrm{C}$ for the leptin plasma RIA assay. 


\section{Tissue isolation and culture of anterior pituitary cells}

AP tissues from each animal were enzymatically dispersed and then cultured as described previously (Bogacka et al. 2002). The number and viabile cells was determined using a haemocytometer and trypan blue (MP Biomedicals, LLC, Santa Ana, CA) exclusion test. The viability of isolated cells exceeded 95\%. The cells were diluted with McCoy's 5a medium (Sigma-Aldrich, USA) containing MEM-non-essential amino acids and vitamins (Sigma-Aldrich, USA), horse serum (10\%; Biomed, Poland) and fetal calf serum (2.5\%; Biomed, Poland) to $2 \times 10^{5}$ cells $/ \mathrm{ml}$, finally placed into 24 -well plates and incubated for $72 \mathrm{~h}$ at $37^{\circ} \mathrm{C}$ in a humidified atmosphere with $5 \% \mathrm{CO}_{2}$. On the day of experiments cells were washed twice with fresh McCoy 5a medium and then incubated for $3.5 \mathrm{~h}$ in $1 \mathrm{ml}$ of serum-free McCoy's 5a medium containing both 20 $\mu \mathrm{M}$ protease inhibitor - bacitracin (Sigma-Aldrich, USA) and respective tested substances: GnRH, leptin or both. As a positive control, cells were treated with $100 \mathrm{ng} / \mathrm{ml}$ of GnRH (Sigma-Aldrich, USA), whereas experimental incubations with $10^{-11}, 10^{-9}$, $10^{-7}, 10^{-6} \mathrm{M}$ leptin (Sigma-Aldrich, USA) were conducted alone or in co-treatment with $100 \mathrm{ng} / \mathrm{ml}$ of GnRH. For each experimental treatment three to six independent cells incubations were performed. After completing experimental protocol media were collected and stored at $-20^{\circ} \mathrm{C}$ until assayed for LH. Cells were scraped, mixed with $1 \mathrm{ml}$ McCoy's 5a medium containing $0.2 \%$ Triton X-100 and bacitracin and obtained cellular suspension was homogenized using polytropic homogenizer (Janke \& Kunkel, IKA Labortechnik, Germany) and frozen at $-20^{\circ} \mathrm{C}$ until LH RIA.

\section{RIA analysis}

LH concentrations in the culture media and cellular homogenates were determined by RIA according to Ziecik et al. (1979) and Szafranska and Tilton (1993). The sensitivity of the assay was $0.08 \mathrm{ng} / \mathrm{ml}$. The intra- and inter-assay coefficients of variation were $8.46 \%$ and $10.54 \%$, respectively. Leptin concentrations in the plasma were determined using Multi-Species Leptin Radioimmunoassay Kit (Millipore, Billerica, MA, USA) according to the manufacturer's protocol. Assay sensitivity was $1 \mathrm{ng} / \mathrm{ml}$; intra-assay coefficient of variation was $8.61 \%$ (in one series).

\section{Total RNA isolation, cDNA synthesis and real-time PCR analysis}

Total RNA was extracted from the tissues (AP and $\mathrm{MBH}$ ) using fenozol (A\&A Biotechnology, Poland) in accordance with the manufacturer's instructions. RNA purity and yield were determined spectrophotometrically (Nanodrop ND-1000, NanoDrop Technologies Inc., USA). Approximately $1 \mu \mathrm{g}$ of RNA was reverse-transcribed into cDNA in a total volume of $20 \mu \mathrm{l}$ with $0.5 \mu \mathrm{g}$ oligo $(\mathrm{dt})_{15}$ primer using the Omniscript RT Kit (Qiagen, USA) at $37^{\circ} \mathrm{C}$ for one hour. A qRT-PCR analysis was performed according to method described previously (Siawrys and Smolinska, 2012) with the use of ABI Prism 7000 Sequence Detection System (Applied Biosystems, Foster City, CA). cDNA samples were amplified in a final reaction volume of $25 \mu$ containing 1x SYBR Green PCR-Master Mix (Applied Biosystems, Foster City, CA, USA) and the respective primers (400 $\mathrm{nmol} / \mathrm{l})$ using the following cycling program: $2 \mathrm{~min}$ at $50^{\circ} \mathrm{C}, 10 \mathrm{~min}$ at $95^{\circ} \mathrm{C}$, followed by $15 \mathrm{sec}$ at $95^{\circ} \mathrm{C}$ and $1 \mathrm{~min}$ at $59^{\circ} \mathrm{C}$ for a total of 46 cycles. The following primer sequences were used: long form of leptin receptor (GenBank acc no. NM001024587) forward 5' AAT CCT CCA GGA GAG CTG TTC ACA C 3' and reverse 5' CTA GGC TCT TGA AGG CTT TCT CAC AT 3; glyceraldehyde 3-phosphate dehydrogenase (GAPDH; GenBank acc no. U48832; ) forward 5' CCT TCA TTG ACC TCC ACT ACA TGG T3' and reverse 5' CCA CAA CAT ACG TAG CAC CAG CAT C 3'. MBH was used as positive control for OB-Rb mRNA expression.

\section{Statistical analysis}

All data are presented as mean \pm SEM. Statistical analysis was performed using the Statistica 6.0 PL program (Stat Soft Inc., USA) and significant differences were determined by one-way ANOVA followed by the least significant difference (LSD) post hoc test. A value of $\mathrm{p}<0.05$ were considered to be statistically significant.

\section{Results}

\section{Leptin plasma concentration}

Plasma leptin concentration was determined by specific RIA method. Obtained results revealed that during implantation period mean serum leptin level reached $3.92 \pm 0.40 \mathrm{ng} / \mathrm{ml}$. 

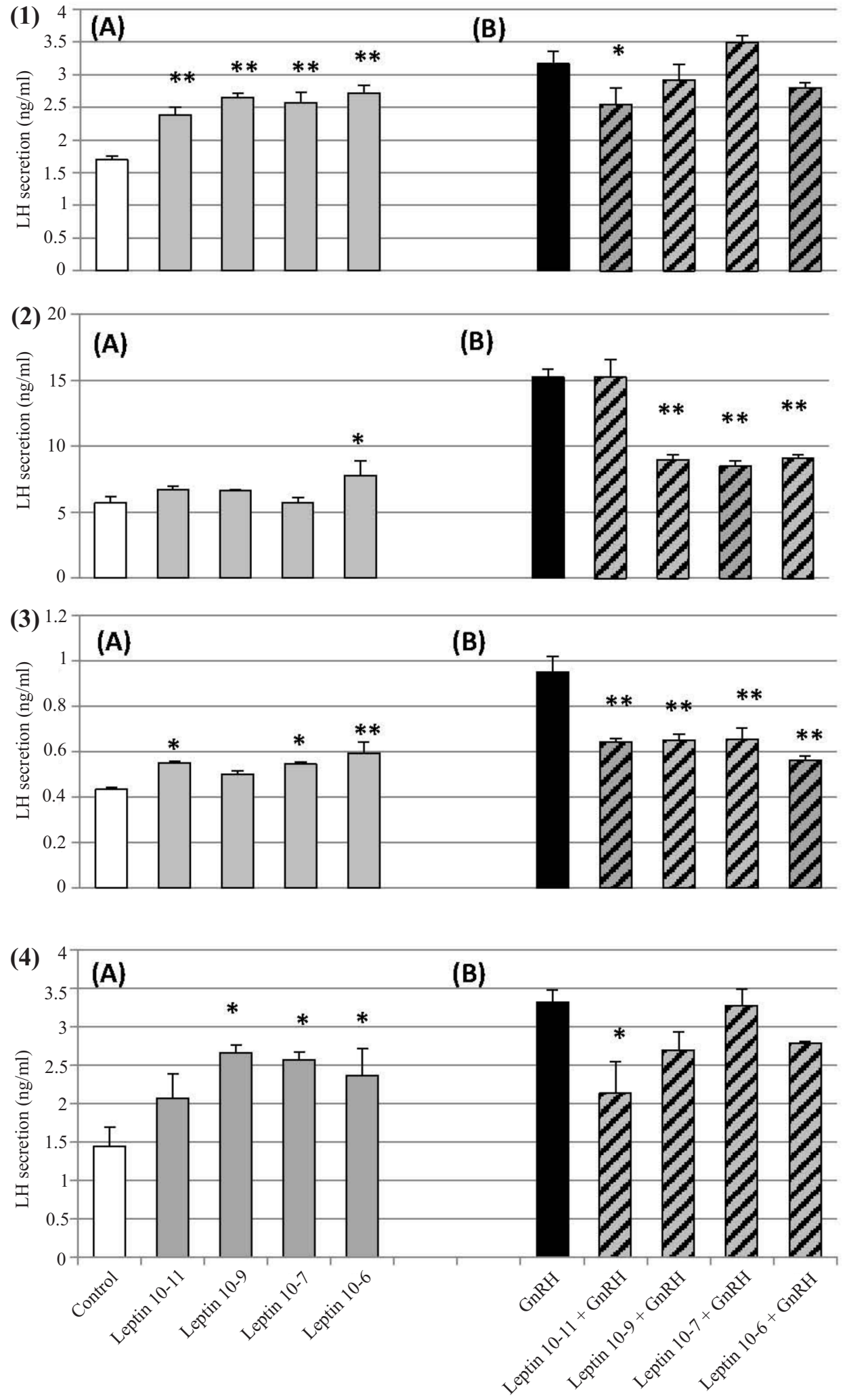

Fig. 1. The effect of leptin $\left(10^{-11}-10^{-6} \mathrm{M}\right)$ on basal (A) and GnRH-induced (B) LH secretion by porcine AP cells on days 14-16 of pregnancy (1-4 = four independent experiments - separate analysis of individual pituitary primary cultures). Values are presented as the mean \pm SEM. Control $=$ basal release in the absence of treatment were $1.70 \pm 0.06 \mathrm{ng} / \mathrm{ml}$; $5.70 \pm 0.49 \mathrm{ng} / \mathrm{ml} ; 0.43 \pm 0.01 \mathrm{ng} / \mathrm{ml}$ and $1.44 \pm 0.26 \mathrm{ng} / \mathrm{ml}$ in four individual experiments, respectively. (A) *,* different from Control $(\mathrm{p}<0.05$ or 0.01$)$; (B) $*{ }^{*}$, different from GnRH alone $(\mathrm{p}<0.05$ or 0.01$)$. 

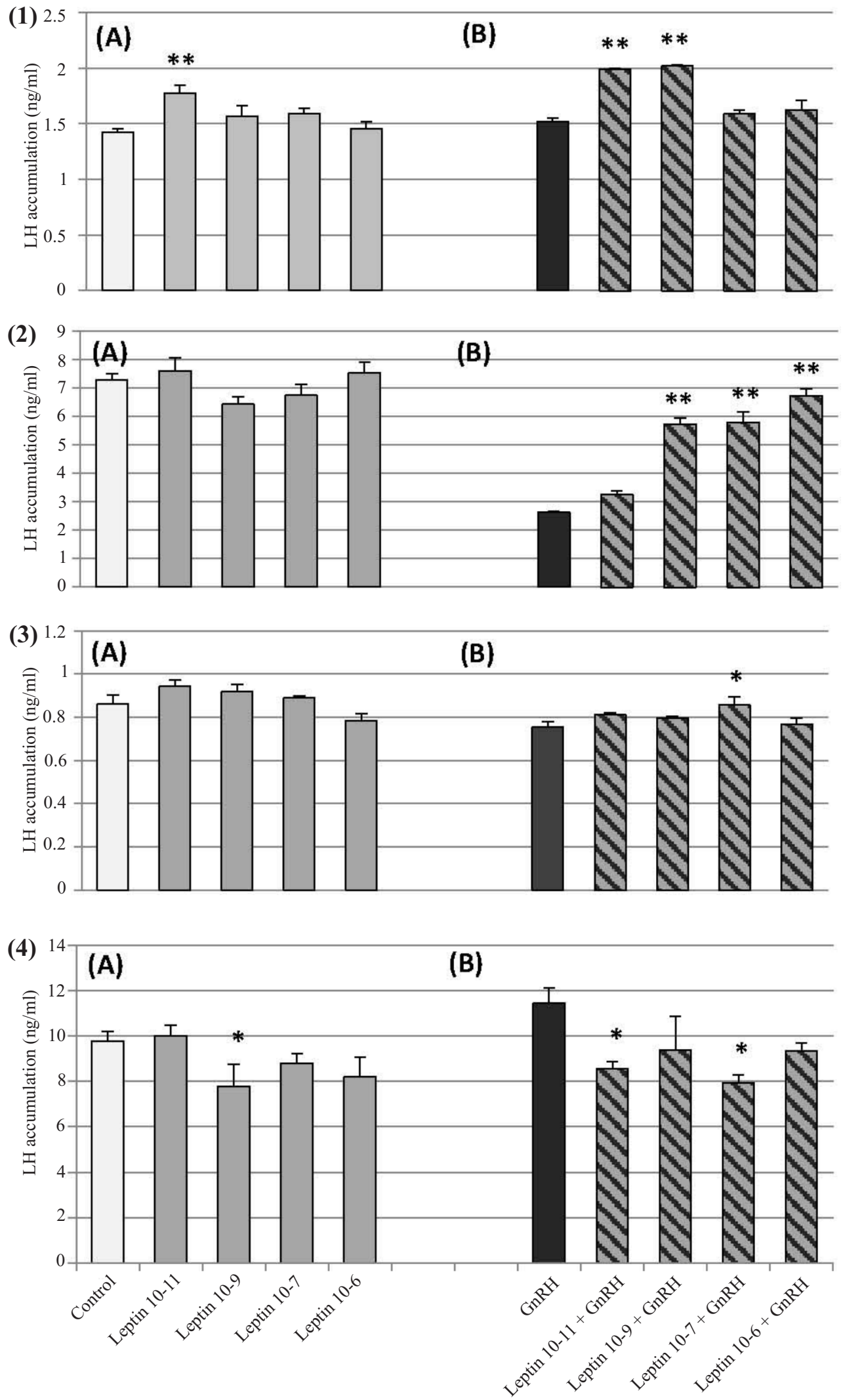

Fig. 2. The effect of leptin $\left(10^{-11}-10^{-6} \mathrm{M}\right)$ on basal (A) and GnRH-induced (B) LH accumulation by porcine AP cells on days 14-16 of pregnancy (1-4 = four independent experiments - separate analysis of individual pituitary primary cultures). Values are presented as the mean \pm SEM. Control $=$ basal accumulations in the absence of treatment were: $1.43 \pm 0.03 \mathrm{ng} / \mathrm{ml}$; $7.28 \pm 0.19 \mathrm{ng} / \mathrm{ml} ; 0.86 \pm 0.04 \mathrm{ng} / \mathrm{ml} ; 9.76 \pm 0.42 \mathrm{ng} / \mathrm{ml}$ in four individual experiments, respectively. (A) *,** different from Control $(\mathrm{p}<0.05$ or 0.01$)$, (B) *,** different from GnRH alone $(\mathrm{p}<0.05$ or 0.01$)$. 


\section{Effects of leptin on basal and GnRH-induced LH secretion from porcine AP cells in vitro}

Obtained results indicate that, depending on individual pituitary primary culture, mean medium LH concentration ranged from $0.43 \pm 0.01 \mathrm{ng} / \mathrm{ml}$ (culture 3) to $5.70 \pm 0.49 \mathrm{ng} / \mathrm{ml}$ (culture 2) in control non-treated cells (Fig. 1). Exogenous leptin, at $10^{-6}$ $M$ concentration, effectively activated LH secretion in all cultures tested, nevertheless a specific dose-response cells sensitivity was also observed. As shown in Fig. 1 only culture 1 responded positively for all tested leptin concentrations, whereas in culture 2 an enhanced LH secretion occurred only in the presence of $10^{-6} \mathrm{M}$ leptin. Although in all cultures exogenous (100 ng/ml) GnRH significantly increased LH secretion in comparison to respective non-treated controls, a broad range of gonadoliberin-induced $\mathrm{LH}$ releasing activity was detected: with minimal $0.95 \pm 0.07 \mathrm{ng} / \mathrm{ml}$ value found in culture 3 and maximal response, reaching 15.25 $\pm 0.58 \mathrm{ng} / \mathrm{ml}$, found in culture 2. Presented data also revealed a down-regulatory effect of exogenous leptin on GnRH-induced LH secretion. This effect was observed in all cultures, however only culture 3 exhibited sensitivity to all leptin concentrations tested. In cultures 1 and 4 only $10^{-11} \mathrm{M}$ leptin significantly reduced LH secretion as compared to respective GnRH-treated group.

Parallel to the analysis of $\mathrm{LH}$ secretion $(\mathrm{ng} / \mathrm{ml})$ in individual pituitary cell culture, a relative data representing a percent of leptin-induced changes vs control or GnRH-only treated groups (both taken as $100 \%$, respectively) is also presented. As shown in Fig. 3, an up-regulatory effect of leptin was observed at all concentrations tested but statistical significance was achieved at three of them with basal LH secretion enhancement by $40 \%, 36 \%$ and by $48 \%$ found in the presence of $10^{-9}, 10^{-7}$ and $10^{-6} \mathrm{M}$ of exogenous leptin, respectively. In contrast, pooled data concerning effects exerted on GnRH-stimulated $\mathrm{LH}$ release revealed that at all concentrations leptin reduced GnRH-induced LH secretion from these cells although only at $10^{-6} \mathrm{M}$ that decrease (by 28\%) reached statistical significance.

\section{Effects of leptin on basal and GnRH-induced intracellular LH accumulation}

At the level of basal LH accumulation exogenous leptin exerted a differentiated effect: with no influence observed in cultures 2 and 3, an up-regulatory action found in culture 1 (only at $10^{-11} \mathrm{M}$ ) and down-regulatory effect observed in culture 4 (only at $\left.10^{-9} \mathrm{M}\right)$. In the presence of $\mathrm{GnRH}$, leptin was able to stimulate LH accumulation in pig anterior pituitary cells and individual cultures exhibited their specific leptin dose-sensitivity. As shown in Fig. 2 culture 2 responded positively to $10^{-9}$ to $10^{-6} \mathrm{M}$ leptin concentration, whereas in culture 3 only at $10^{-7} \mathrm{M}$ leptin was effective. Interestingly, in culture 2 leptin effect on GnRH-induced LH secretion and LH intracellular accumulation was inversely-related. Indeed, its down-regulatory (at $10^{-9} 10^{-7}$ and $10^{-6} \mathrm{M}$ ) action exerted on GnRH-stimulated LH secretion (Fig. 1) was accompanied by simultaneous up-regulatory effect of leptin on LH accumulation in anterior pituitary cells (Fig. 2). In turn, in culture 4 leptin in the presence of GnRH down-regulated LH accumulation. In pooled data analysis no effect of leptin on basal and GnRH-stimulated LH intracellular accumulation was found (Fig. 3).

\section{Localization of OB-Rb gene expressions in porcine AP gland}

OB-Rb transcript was detected in porcine AP gland and in $\mathrm{MBH}$, which served as a positive control, on days 14-16 of pregnancy. The negative control sample (NTC) did not reveal products of the qRT-PCR reaction. The obtained transcripts were sequenced (ABI Prism 3777 DNA sequencer) at the Institute of Biochemistry and Biophysics of the Polish Academy of Science and 95\% homology to porcine OB-Rb sequence was confirmed.

\section{Discussion}

Presented results indicate a differentiated dose-sensitivity of individual anterior pituitary culture for exogenous leptin stimulation in respect to basal and GnRH-stimulated LH secretion and intracellular accumulation. Moreover, a dual and dose-dependent action of leptin on LH secretion was found with up-regulatory effect found when applied alone and down-regulatory when given in the presence of GnRH.

Presented data are in accordance with previous studies which indicated stimulatory action of leptin on basal LH release from pig AP gland (Barb et al. 2004, Nonaka et al. 2006). LH-activating leptin activity was also reported in anterior pituitary cells of female (Ogura et al. 2001, Tezuka et al. 2002) and male (Yu et al. 1997) rat hemi-anterior pituitaries. Pro-gonadotrophic stimulation was also shown in female rats at the time of spontaneous and steroid-induced LH surge (De Biasi et al. 2001) and leptin 
(1)

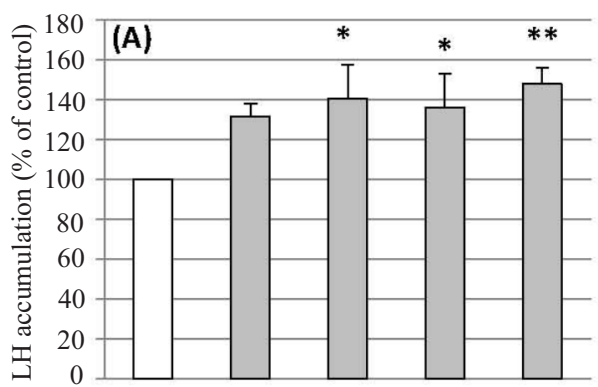

(2)

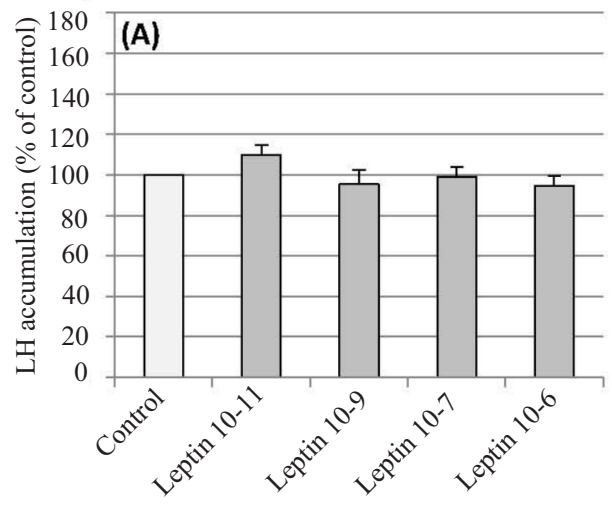

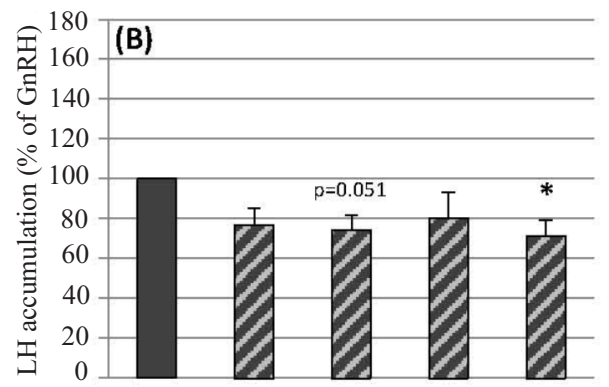

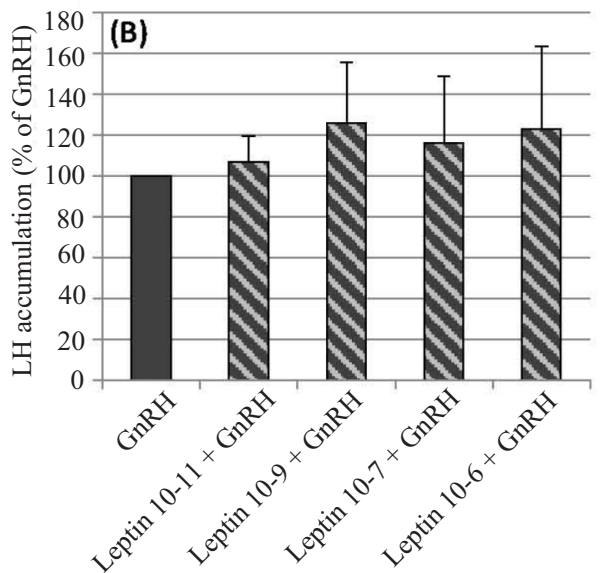

Fig. 3. The effect of leptin $\left(10^{-11}-10^{-6} \mathrm{M}\right)$ on basal (A) and GnRH-induced (B) LH secretion (1) or accumulation (2) by porcine AP cells on days 14-16 of pregnancy (a pooled analysis of four independent experiments). Values are presented as a percentage (mean \pm SEM) of basic LH release (1) or accumulation (2) established in (A) control group of cells $(=100 \%)$ or (B) GnRH (without leptin) group of cells $(=100 \%)$. (1) Control = basal release in the absence of treatment was $2.32 \pm 1.16 \mathrm{ng} / \mathrm{ml}, \mathrm{GnRH}$-induced release (without leptin) was $5.67 \pm 3.24 \mathrm{ng} / \mathrm{ml}$. (A) *, ** different from Control (p<0.05 or $0.01)$; $(\mathrm{B}) *$ different from $\mathrm{GnRH}$ alone $(\mathrm{p}<0.05)$. (2) Control = basal accumulation in the absence of treatment was $4.83 \pm 2.19 \mathrm{ng} / \mathrm{ml}, \mathrm{GnRH}$-induced accumulation (without leptin) was $4.08 \pm 2.48 \mathrm{ng} / \mathrm{ml}$. (A) Leptin-treated cultures were not different from Control; (B) Leptin-treated cultures were not different from GnRH alone.

concentrations maximally effective in basal LH release stimulation were similar to levels in juvenile, pubertal and mature female rats serum (Ogura et al. 2001, Tezuka et al. 2002).

Some data indicate a broad-range pituitary cells sensitivity to leptin stimulation. Indeed, leptin at concentration from $10^{-14}$ to $10^{-6} \mathrm{M}$, except for $10^{-12}$ and $10^{-7} \mathrm{M}$ was shown to increase basal pituitary $\mathrm{LH}$ release (Barb et al. 2004) in prepubertal gilts. However, in another study on prepubertal barrows/gilts, leptin only at $10^{-8}$ and $10^{-7} \mathrm{M}$ concentration evoked a stimulatory LH response (Nanoka et al. 2006). Also in vitro studies revealed that, at concentration from $10^{-11} \mathrm{M}$ to $10^{-7} \mathrm{M}$ of leptin increased basal $\mathrm{LH}$ release from juvenile female rat AP cells and observed effects showed a bell-shaped dose-response curve (Tezuka et al. 2002). In our present study, however, a culture-specific pattern of response for different leptin concentrations was observed with a $10^{-6} \mathrm{M}$ being effective in $\mathrm{LH}$ basal release stimulation in four individual pituitaries-derived cultures.
Our individual and pooled data analysis revealed that in contrast to up-regulatory effects exerted by leptin given alone, its co-administration with gonadoliberin diminished GnRH-evoked LH releasing activity. Similarly, in study on prepubertal gilts Barb et al. (2004) reported a down regulatory activity of exogenous $10^{-7} \mathrm{M}$ leptin on $10^{-8} \mathrm{M}$ GnRH-stimulated $\mathrm{LH}$ release as well as $10^{-13} \mathrm{M}$ leptin on $10^{-9}$ M GnRH-induced LH release whereas at other leptin concentrations tested no such effect was observed. Also in sows, leptin at concentration of $10^{-9}$ $-10^{-7} \mathrm{M}$ increased, at $10^{-6} \mathrm{M}$ decreased, whereas at $10^{-11}-10^{-10} \mathrm{M}$ did not affect GnRH-induced LH secretion from pituitary cell culture during follicular phase estrous cycle (Kosior-Korzecka and Bobrowiec 2007). Furthermore, stimulatory influence of leptin on GnRH-induced LH release from AP pituitary cells was reported in juvenile (Tezuka et al. 2002) and pubertal (Ogura et al. 2001) rats and observed effect expressed as a bell-shaped dose-response curve. No leptin activity was found in respect to the 
modulation of $\mathrm{LH}$ release from $\mathrm{GnRH}$-activated hemi-anterior pituitaries of adult male ( $\mathrm{Yu}$ et al. 1997) as well as proestrus rats (Peters et al. 2009). Leptin was also shown to enhance GnRH-mediated secretion of LH from AP explants of normal-fed, but not of fasted, cows (Amstalden et al. 2003). Taken together, available data clearly indicate the existence of the precise mechanism responsible for physiological status-dependent gonadotrophic cells sensitivity for leptin stimulation.

In pooled data analysis no effects of leptin on basal and GnRH-induced LH accumulation in AP cells were shown. Opposite results were reported in rats in which increase of basal and GnRH-induced cellular LH level was dependent on applied leptin concentration (Ogura et al. 2001, Tezuka et al. 2002) with $10^{-10} \mathrm{M}$ being effective in basal whereas $10^{-10}$, $10^{-9}$ and $10^{-8} \mathrm{M}$ in GnRH-induced stimulation of intracellular LH accumulation (Ogura et al. 2001). An existing differences between studies concerning gonadotrope cells response for exogenous leptin stimulation may result both from age and reproductive/endocrine status of tested animals, their metabolic state as well as from specific applied experimental protocol (e.g. type and duration of cell culture, doses of treatments). Moreover, also specific cellular composition of each culture might contribute for their experimentally observed differentiated leptin dose-sensitivity. Nevertheless, taking collectively, available data clearly indicate that leptin participates in the regulation of $\mathrm{LH}$ release from gonadotrope cells and its effect is dual: stimulatory, when related to basal secretion, but can be inhibitory in respect to GnRH-mediated release.

Leptin acts on LH secretory activity via its specific receptor and is able to autoregulate its own receptors expression (Di Yorio et al. 2008) and pituitary-derived leptin may act as an autocrine/paracrine factor within AP gland. Studies, primarily on ruminants and laboratory rodents, have established that leptin receptor is expressed in all types of AP cells, including gonadotropes (Iqbal et al. 2000, Sone et al. 2001). However, to date no data on leptin receptor localization in porcine AP specific cell subtypes are available. Present research confirmed the presence of OB-Rb in the AP gland in the pregnant gilts. In previous studies both long and short isoforms of leptin receptor in AP gland in the pregnant as well as cyclic pigs were detected (Bogacka et al. 2006, Siawrys et al. 2007) and changes in leptin receptor expression observed during different stages of gestation and estrous cycle were suggested to be related to the physiological fluctuation of gonadal steroid status in these animals (Kaminski et al. 2006, Siawrys et al. 2007).
In our study also leptin plasma level in pregnant gilts was determined. Obtained result revealed that in contrast to well recognized pattern found in humans and rodents, porcine leptin plasma concentration has not changed during the estrous cycle as well as between gestation and the cycle (unpublished own data). Serum leptin concentration varied significantly during the menstrual cycle in women with higher leptin levels observed in the luteal than in the follicular phase (Ahrens et al. 2014). Cycle-dependent changes in leptin concentration have been also reported in female rats with a peak value appearing at proestrous (Fungfuang et al. 2013) what indicates a cycle-specific interplay among leptin and reproductive hormones $\left(\mathrm{E}_{2}, \mathrm{P}_{4}, \mathrm{LH}, \mathrm{FSH}\right)$ concentrations (Ahrens et al. 2014). In humans and rodents serum leptin levels were shown to increase during pregnancy due to enhanced leptin synthesis by both maternal and fetal adipose tissues as well as by trophoblast (Henson and Castracane 2000). In pregnant sows, however, serum leptin concentration was not sensitive to body weight enhancement (Estienne et al. 2003, Metges et al. 2012) what indicates a differences in leptin physiology between species.

In conclusion, in this study we found that anterior pituitary primary cultures derived from individual pituitaries obtained from pigs at early pregnancy maintain a differentiated dose-sensitivity to exogenous leptin stimulation in respect to LH secretion. Collectively, a dual and dose-dependent action of leptin on LH secretion was found with up-regulatory effect observed when applied alone and down-regulatory when given in the presence of GnRH. These data indicate that leptin alone, as well as in combination with gonadoliberin, can specifically, at the pituitary level, modulate LH secretory activity during early pregnancy in pigs.

\section{Acknowledgements}

The authors express their grateful appreciation to Professor Jadwiga Przała (UWM, Olsztyn) for her generous support. This research was financed by the State Committee for Scientific Research (project: No. PBZ-KBN 084/PO6/2002), the Ministry of Science and Higher Education (project: N N311 098634) and grant from University of Warmia and Mazury in Olsztyn (020600.0205).

\section{References}

Ahrens K, Mumford SL, Schliep KC, Kissell KA, Perkins NJ, Wactawski-Wende J, Schisterman EF (2014) Serum leptin levels and reproductive function during the menstrual cycle. Am J Obstet Gynecol 210: 248.e1-9. 
Amstalden M, Zieba DA, Edwards JF, Harms PG, Welsh TH Jr, Stanko RL, Williams GL (2003) Leptin acts at the bovine adenohypophysis to enhance basal and gonadotropin-releasing hormone-mediated release of luteinizing hormone: differential effects are dependent upon nutritional history. Biol Reprod 69: 1539-1544.

Barb CR, Barrett JB, Kraeling RR (2004) Role of leptin in modulating the hypothalamic-pituitary axis and luteinizing hormone secretion in the prepuberal gilt. Domest Anim Endocrinol 26: 201-214.

Bogacka I, Przała J, Siawrys G, Kaminski T, Smolinska $\mathrm{N}$ (2006) The expression of short form of leptin receptor gene during early pregnancy in the pig examined by quantitative real time RT-PCR. J Physiol Pharmacol 57: 479-489.

Bogacka I, Siawrys G, Okrasa S, Kaminski T, Przala J (2002) The influences of GnRH, oxytocin and vasoactive intestinal peptide on LH and PRL secretion by porcine pituitary cells in vitro. J Physiol Pharmacol 53: 439-451.

Chehab FF (2014) 20 years of leptin: leptin and reproduction: past milestones, present undertakings, and future endeavors. J Endocrinol 223: T37-48.

Counis R, Garrel G, Laverriere JN, Simon V, Bleux C, Magre S, Cohen-Tannoudji J (2009) The GnRH receptor and the response of gonadotrope cells to GnRH pulse frequency code. A story of an atypical adaptation of cell function relying on a lack of receptor homologous desensitization. Folia Histochem Cytobiol 47: S81-7.

De Biasi SN, Apfelbaum LI, Apfelbaum ME (2001) In vitro effect of leptin on LH release by anterior pituitary glands from female rats at the time of spontaneous and steroid-induced LH surge. Eur J Endocrinol 145: 659-665.

Di Yorio MP, Bilbao MG, Pustovrh MC, Prestifilippo JP, Faletti AG (2008) Leptin modulates the expression of its receptors in the hypothalamic-pituitary-ovarian axis in a differential way. J Endocrinol 198: 355-366.

Estienne MJ, Harper AF, Kozink DM, Knight JW (2003) Serum and milk concentrations of leptin in gilts fed a high- or low-energy diet during gestation. Anim Reprod Sci 75: 95-105.

Estienne MJ, Barb CR (2005) The control of adenohypophysial hormone secretion by amino acids and peptides in swine. Domest Anim Endocrinol 29: 34-42.

Ezzat AA, Saito H, Sawada T, Yaegashi T, Goto Y, Nakajima Y, Jin J, Yamashita T, Sawai K, Hashizume $\mathrm{T}$ (2010) The role of sexual steroid hormones in the direct stimulation by Kisspeptin-10 of the secretion of luteinizing hormone, follicle-stimulating hormone and prolactin from bovine anterior pituitary cells. Anim Reprod Sci 121: 267-272.

Fruhbeck G (2006) Intracellular signalling pathways activated by leptin. Biochem J 393: 7-20.

Fungfuang W, Nakada T, Nakao N, Terada M, Yokosuka M, Gizurarson S, Hau J, Moon C, Saito TR (2013) Serum leptin concentrations, leptin mRNA expression, and food intake during the estrous cycle in rats. Lab Anim Res 29: 1-6.

Henson MC, Castracane VD (2000) Leptin in pregnancy. Biol Reprod 63: 1219-1228.

Iqbal J, Pompolo S, Considine RV, Clarke IJ (2000) Localization of leptin receptor-like immunoreactivity in the corticotropes, somatotropes, and gonadotropes in the ovine anterior pituitary. Endocrinology 141: 1515-1520.
Kaminski T, Smolinska N, Gajewska A, Siawrys G, Okrasa S, Kochman K, Przala J (2006) Leptin and long form of leptin receptor genes expresssion in the hypothalamus and pituitary during the luteal phase and early pregnancy in pigs. J Physiol Pharmacol 57: 95-108.

Kirsz K, Szczesna M, Dudek K, Bartlewski PM, Zieba DA (2014) Influence of season and nutritional status on the direct effects of leptin, orexin-A and ghrelin on luteinizing hormone and growth hormone secretion in the ovine pituitary explant model. Domest Anim Endocrinol 48: $69-76$.

Kosior-Korzecka U, Bobowiec R (2007) Effect of leptin, insulin, and IGF-I on GnRH-induced LH secretion from porcine pituitary cells in vitro. Bull Vet Inst Pulawy 51: 439-443.

Lin J, Barb CR, Matteri RL, Kraeling RR, Chen X, Meinersmann RJ, Rampacek GB (2000) Long form leptin receptor mRNA expression in the brain, pituitary, and other tissues in the pig. Domest Anim Endocrinol 19: 53-61.

Metges CC, Lang IS, Hennig U, Brussow KP, Kanitz E, Tuchscherer M, Schneider F, Weitzel JM, Steinhoff-Ooster A, Sauerwein H, Bellmann O, Nürnberg G, Rehfeldt $\mathrm{C}$, Otten W (2012) Intrauterine growth retarded progeny of pregnant sows fed high protein:low carbohydrate diet is related to metabolic energy deficit. PLoS One 7: e31390.

Naor Z, Huhtaniemi I (2013) Interactions of the GnRH receptor with heterotrimeric $\mathrm{G}$ proteins. Front Neuroendocrinol 34: 88-94.

Nonaka S, Hashizume T, Yamashita T (2006) Effects of leptin and leptin peptide amide on the release of luteinizing hormone, growth hormone and prolactin from cultured porcine anterior pituitary cells. Anim Sci J 77: 47-52.

Ogura K, Irahara M, Kiyokawa M, Tezuka M, Matsuzaki T, Yasui T, Kamada M, Aono T (2001) Effects of leptin on secretion of LH and FSH from primary cultured female rat pituitary cells. Eur J Endocrinol 144: 653-658.

Pelleymounter MA, Cullen MJ, Baker MB, Hecht R, Winters D, Boone T, Collins F (1995) Effects of the obese gene product on body weight regulation in ob/ob mice. Science 269: 540-543.

Perez-Perez A, Sanchez-Jimenez FS, Maymo J, Duenas JL, Varone C, Sanchez-Margalet V (2015) Role of leptin in female reproduction. Clin Chem Lab Med 53: 15-28.

Peters EE, Towler KL, Mason DR, Evans JJ (2009) Effects of galanin and leptin on gonadotropin-releasing hormone-stimulated luteinizing hormone release from the pituitary. Neuroendocrinology 89: 18-26.

Siawrys G, Kaminski T, Smolinska N, Przala J (2007) Expression of leptin and long form of leptin receptor genes and proteins in pituitary of cyclic and pregnant pigs. J Physiol Pharmacol 58: 845-857.

Siawrys G, Kaminski T, Smolinska N, Przala J (2009) Expression of leptin and long-form leptin-receptor proteins in porcine hypothalamus during oestrous cycle and pregnancy. Reprod Domest Anim 44: 920-926.

Siawrys G, Smolinska N (2012) Direct in vitro effect of LH and steroids on leptin gene expression and leptin secretion by porcine luteal cells during the mid-luteal phase of the estrous cycle. Reprod Biol 12: 317-323. 
Sone M, Nagata H, Takekoshi S, Osamura RY (2001) Expression and localization of leptin receptor in the normal rat pituitary gland. Cell Tissue Res 305: 351-356.

Szafranska B, Tilton JE (1993) Prolactin as a luteotrophin during late pregnancy in pigs. J Reprod Fertil 98: 643-648.

Tezuka M, Irahara M, Ogura K, Kiyokawa M, Tamura T, Matsuzaki T, Yasui T, Aono T (2002) Effects of leptin on gonadotropin secretion in juvenile female rat pituitary cells. Eur J Endocrinol 146: 261-266.

Yu WH, Kimura M, Walczewska A, Karanth S, McCann SM (1997) Role of leptin in hypothalamic-pituitary function. Proc Natl Acad Sci USA 94: 1023-1028.

Ziecik A, Goralska M, Krzymowski T, Pogorzelski K (1979) Isolation and purification of porcine $\mathrm{LH}$ for radioimmunoassay and radioreceptor assay. Bull Acad Pol Sci Biol 26: 739-744. 